\title{
EVALUATION OF UPPER GASTROINTESTINAL ENDOSCOPY IN PATIENTS UNDERGOING BARIATRIC SURGERY
}

\author{
Análise dos resultados da endoscopia digestiva alta nos pacientes em pré-operatório de cirurgia bariátrica
}

\author{
Maurício Saab ASSEF, Tiago Torres MELO, Osvaldo ARAKI, Fábio MARIONI
}

From the Serviço de Endoscopia, Departamento de Cirurgia, Santa Casa de São Paulo (Service of Endoscopy, Department of Surgery, Santa Casa de São Paulo) São Paulo, SP, Brazil

HEADINGS - Obesity. Bariatric surgery. Endoscopy.
ABSTRACT - Background: Obesity has become epidemic, and is associated with greater morbidity and mortality. Treatment is multidisciplinary. Surgical treatment is a consistent resource in severe obesity. The indication of preoperative upper gastrointestinal endoscopy in asymptomatic patients is controversial; however, most studies recommend its implementation in all patients. Aim: To analyze endoscopic performance in patients who were in preoperative for bariatric surgery and compare them with control group. Method: A series of 35 obese patients in preoperative period for bariatric surgery compared with a control group of 30 patients submitted to upper endoscopy. There were analyzed clinical and endoscopic data. Results: The mean age of the group of patients was 43.54 years. Most individuals in the group of patients were female with median BMI of $47.26 \mathrm{~kg} / \mathrm{m}^{2}$ and in control group $24.21 \mathrm{~kg} /$ $\mathrm{m}^{2}$. The majority of patients were asymptomatic. Upper endoscopy was altered in $81.25 \%$ of asymptomatic patients. Endoscopic findings in the patient group were $57.1 \%$ resulting from peptic ulcer disease and 34.3\% associated with GERD. The analysis of endoscopic findings in patients showed no significant difference in relation of the control group. The prevalence of $H$. pylori infection was $60 \%$ in patients. Conclusion: It is recommended that the upper endoscopy should be made in all patients in the preoperative bariatric surgery period, although the degree of obesity is not related to a greater number of endoscopic findings. Obese patients do not have more endoscopic findings that non-obese individuals.

\section{Correspondence:}

Maurício Saab Assef

E-mails: msassef@terra.com.br /

tiagotor85@hotmail.com

Financial source: none

Conflicts of interest: none

Received for publication: 19/03/2015 Accepted for publication: 02/07/2015

DESCRTORES: Obesidade. Cirurgia bariátrica. Endoscopia..
RESUMO - Racional: A obesidade tornou-se epidemia e está associada à maior morbimortalidade. Seu tratamento é multidisciplinar. O tratamento cirúrgico é recurso consistente nos casos de obesidade grave. A indicação da endoscopia digestiva alta pré-operatória em pacientes assintomáticos é controversa; no entanto, a maioria dos estudos recomenda sua realização em todos os pacientes. Objetivo: Analisar os resultados da endoscopia em pacientes que se encontravam em préoperatório de cirurgia bariátrica, e compará-los aos achados do grupo controle. Método: Série de 35 pacientes obesos em pré-operatório de cirurgia bariátrica com um grupo controle de 30 pacientes submetidos à endoscopia no período de fevereiro a julho de 2014. Foram analisados dados clínicos e endoscópicos. Resultados: A média de idade do grupo de pacientes foi de 43,54 anos e a maioria deste grupo era do sexo feminino. A média do valor do IMC no grupo de pacientes foi de $47,26 \mathrm{~kg} / \mathrm{m} 2$ e no grupo controle de $24,21 \mathrm{~kg} / \mathrm{m}^{2}$. A maioria dos pacientes era assintomática. A endoscopia estava alterada em $81,25 \%$ dos pacientes assintomáticos. As alterações endoscópicas no grupo de pacientes foram $57,1 \%$ decorrentes da doença ulceropéptica e $34,3 \%$ associadas à DRGE. A análise do número de achados endoscópicos no grupo de pacientes em relação ao grupo controle não demonstrou diferença estatística significante. A prevalência da infecção do $H$. pylori foi de $60 \%$ no grupo de pacientes. Conclusão: Recomenda-se que a endoscopia digestiva alta deva ser realizada em todos pacientes em pré-operatório de cirurgia bariátrica, embora o grau de obesidade não tenha relação com maiores alterações endoscópicas. Os obesos não têm maior número de alterações endoscópicas que os não obesos.

INTRODUCTION

$\mathrm{O}$ besity has become epidemic and is associated with increased morbidity secondary to various factors (comorbidities), including gastroesophageal reflux disease. These associated factors increase mortality ${ }^{1-5}$. Reaches 600 million people worldwide and 30 million in Brazil. Including the population with overweight, the figure rises to 1.9 billion people worldwide and 95 million Brazilians ${ }^{3}$. Obesity is defined according to body mass index (BMI) greater or equal to $30^{1-3}$.

Treatment is multidisciplinary and includes dietary measures, behavioral, exercise, medications, endoscopic and surgical methods ${ }^{1,2,6}$. Surgical treatment is consistent feature in severe obesity (IMC $\geq 40$ or $\geq 35$ associated with comorbidities) with clinical treatment failure, reducing mortality rates and improving clinical comorbidities ${ }^{1,4}$. Surgical techniques can be restrictive (adjustable gastric banding, sleeve gastrectomy), disabsortive (duodenal switch, Scopinaro operation) or mixed (Roux-en-Y gastric bypass) ${ }^{6}$.

In the preoperative of patients with bariatric surgical indication, as well as history and appropriate physical examination, laboratory tests are required, including upper endoscopy (EDA). Its use in preoperatively asymptomatic patients is controversial ${ }^{4,8,9}$; however, most studies and societies recommend it in all patients ${ }^{4-8,10}$ for identifying 
various diseases to be treated before surgery. It may also suggest modification of surgical technique to be employed and to contraindicate the operation ${ }^{4-8}$. Studies have shown endoscopic findings in $80 \%$ of asymptomatic patients ${ }^{7,8}$.

The most frequent endoscopic findings are hiatal hernia, gastritis, esophagitis, gastroduodenal ulcers and Barrett's esophagus $4,7,8$. The stomach is the most affected segment up about $80 \%$ of the cases ${ }^{5}$.

The prevalence of Helicobacter pylori infection in individuals with bariatric surgery indication in the literature ranges from $8,7 \%^{5}$ to $30-40 \%{ }^{4,11}$ of cases. It is recommended its search and pre-operative treatment ${ }^{4}$, since it is associated with higher incidence of gastric cancer ${ }^{12}$ and anastomotic mouth ulcers ${ }^{4}$.

The aim of this study was to analyze the EDA results in patients who were in pre-bariatric surgery, and underwent the procedure at the Endoscopy Unit of the Santa Casa de São Paulo, São Paulo, SP, Brazil, and compare them to findings in control group.

\section{METHOD}

This study was approved by the Ethics Committee of the Santa Casa de São Paulo. The subjects involved were in agreement and consented to participate in the research and dissemination of its results in accordance with Resolution 196/96 of the National Health Council.

\section{Patients}

The sample consisted of two groups, one being the control group. Were analyzed 35 patients in the group of obese in the preoperative period for bariatric surgery and 30 non-obese in the control group. The number of cases was calculated to obtain sample force power to $80 \%$ and significance level of $5 \%$ $(p=0.05)$. All patients underwent endoscopy during the period from February to July 2014.

Were included in the study group those patients appointment to preoperative bariatric surgery survey. Were excluded those who refused to participate.

The control group was formed by a pairing of patients according to gender, age and use of proton pump inhibitors (PPIs). The age of the control group was established by calculating the average age range of bariatric patients, using $95 \%$ confidence interval.

Were included patients in the control group that had indication for EDA and with lower BMI than or equal to 29.9, being normal (BMI: 18.5 to 24.9) or overweight (BMI 25 to 29.9). Were excluded obese patients $(B M I \geq 30)$ and the ones with gastrointestinal tract malignancy, stenosis, having prior gastrointestinal surgery or refused to participate.

The variables analyzed were age, BMI, use of PPIs, symptoms, endoscopic findings, complications of the procedure, prevalence of infection of Helicobacter pylori.

\section{Endoscopy}

Patients underwent to a questionnaire (protocol), followed by the completion of the endoscopic examination with standard $9.8 \mathrm{~mm}$ videoendoscope under sedation and topical anesthesia. The research for Helicobacter pylori was done by two methods: pathology and urease test, given as positive if any one of them was positive. Endoscopic findings were divided into ulceropeptic disease - gastritis, bulboduodenitis and peptic ulcers -; associated with gastroesophageal reflux disease esophagitis, hiatal hernia, Barrett's esophagus -; polyps; others (diverticula, gastric intestinal metaplasia, etc.)

\section{Statistical analysis}

For the organization of the data was used the spreadsheet MS-Excel version of MS-Office 2010, and to achieve the results was used IBM SPSS (Statistical Package for Social Sciences), version 22.0. The qualitative variables were represented by absolute frequency ( $\mathrm{n}$ ) and relative (\%) and quantitative by average, standard deviation and median (md). Applying the Spearman, correlation analysis was performed in order to verify the degree of relationship between some of the variables. The application of Fisher's exact test was performed to verify possible differences between both groups for the variables of interest. The correlation coefficient $(r)$ between the variables was determined as positive or negative. The significance level (p) was considered as less than $5 \%(p<0.05)$.

\section{RESULTS}

The average age of the group of patients was 43.54 years (25-64) and the control group of 40.53 years (38-44) (Table 1$)$.

TABLE 1 - Distribution of patients and the control group according to age and BMI

\begin{tabular}{|c|c|c|c|c|c|c|c|c|c|}
\hline Variable & Group & $\mathrm{n}$ & Mean & $\begin{array}{l}\text { Standard } \\
\text { deviation }\end{array}$ & Mirimum & Maximum & $\begin{array}{l}\text { Percentile } \\
25\end{array}$ & $\begin{array}{c}\text { Percentile } \\
50 \\
\text { (median) }\end{array}$ & $\begin{array}{l}\text { Percentile } \\
75\end{array}$ \\
\hline \multirow{2}{*}{ Age } & Patient & 35 & 43,54 & 10,94 & 25,00 & 64,00 & 36,00 & 42,00 & 54,00 \\
\hline & Control & 30 & 40,53 & 1,70 & 38,00 & 44,00 & 39,00 & 40,50 & 42,00 \\
\hline \multirow{2}{*}{ IMC } & Patient & 35 & 47,26 & 6,21 & 38,00 & 68,00 & 43,10 & 45,90 & 49,50 \\
\hline & Control & 30 & 24,21 & 1,98 & 21,00 & 28,00 & 22,68 & 23,80 & 25,90 \\
\hline
\end{tabular}

Most individuals of both groups, patients and control, were women in $91.4 \%$ and $83.3 \%$, respectively (Table 2 ).

TABLE 2 - Distribution of patient and the control groups by categorical variables

\begin{tabular}{|c|c|c|c|c|c|}
\hline \multirow{3}{*}{ Variable } & \multirow{3}{*}{ Category } & \multicolumn{4}{|c|}{ Group } \\
\hline & & \multicolumn{2}{|c|}{ Patient } & \multicolumn{2}{|c|}{ Control } \\
\hline & & Freq. & Perc. & Freq. & Perc. \\
\hline \multirow{2}{*}{ Gender } & $\mathrm{F}$ & 32 & $91,40 \%$ & 25 & $83,30 \%$ \\
\hline & M & 3 & $8,60 \%$ & 5 & $16,70 \%$ \\
\hline \multirow{2}{*}{ BMI } & Normal & 0 & $0,00 \%$ & 21 & $70,00 \%$ \\
\hline & Overweight & 0 & $0,00 \%$ & 9 & $30,00 \%$ \\
\hline \multirow{2}{*}{ PPI user } & Yes & 5 & $14,30 \%$ & 16 & $53,30 \%$ \\
\hline & No & 30 & $85,70 \%$ & 14 & $46,70 \%$ \\
\hline \multirow{2}{*}{ Symptomatic } & Yes & 3 & $8,60 \%$ & 24 & $80,00 \%$ \\
\hline & No & 32 & $91,40 \%$ & 6 & $20,00 \%$ \\
\hline \multirow{2}{*}{ Pyrosis } & Yes & 2 & $5,70 \%$ & 8 & $26,70 \%$ \\
\hline & No & 33 & $94,30 \%$ & 22 & $73,30 \%$ \\
\hline \multirow{2}{*}{ Regurgitation } & Yes & 1 & $2,90 \%$ & 7 & $23,30 \%$ \\
\hline & No & 34 & $97,10 \%$ & 23 & $76,70 \%$ \\
\hline \multirow{2}{*}{ Epigastralgia } & Yes & 1 & $2,90 \%$ & 18 & $60,00 \%$ \\
\hline & No & 34 & $97,10 \%$ & 12 & $40,00 \%$ \\
\hline \multirow{2}{*}{ Other symptom } & Yes & 1 & $2,90 \%$ & 1 & $3,30 \%$ \\
\hline & No & 34 & $97,10 \%$ & 29 & $96,70 \%$ \\
\hline \multirow{2}{*}{ Normal } & Yes & 7 & $20,00 \%$ & 10 & $33,30 \%$ \\
\hline & No & 28 & $80,00 \%$ & 20 & $66,70 \%$ \\
\hline \multirow{2}{*}{$\begin{array}{l}\text { Endoscopic finding } \\
\text { - DUP }\end{array}$} & Yes & 20 & $57,10 \%$ & 15 & $50,00 \%$ \\
\hline & No & 15 & $42,90 \%$ & 15 & $50,00 \%$ \\
\hline \multirow{2}{*}{$\begin{array}{l}\text { Endoscopic finding } \\
\text { - DRGE }\end{array}$} & Yes & 12 & $34,30 \%$ & 7 & $23,30 \%$ \\
\hline & No & 23 & $65,70 \%$ & 23 & $76,70 \%$ \\
\hline \multirow{2}{*}{$\begin{array}{l}\text { Endoscopic finding } \\
\text { - polyp }\end{array}$} & Yes & 4 & $11,40 \%$ & 2 & $6,70 \%$ \\
\hline & No & 31 & $88,60 \%$ & 28 & $93,30 \%$ \\
\hline \multirow{2}{*}{$\begin{array}{l}\text { Endoscopic finding - } \\
\text { others }\end{array}$} & Yes & 3 & $8,60 \%$ & 2 & $6,70 \%$ \\
\hline & No & 32 & $91,40 \%$ & 28 & $93,30 \%$ \\
\hline \multirow{2}{*}{ Helicobacter pylori } & Positive & 21 & $60,00 \%$ & 12 & $40,00 \%$ \\
\hline & Negative & 14 & $40,00 \%$ & 18 & $60,00 \%$ \\
\hline
\end{tabular}

$\mathrm{PPI}=$ proton pump inhibitor; $\mathrm{DUP}=$ ulceropeptic disease; $\mathrm{DRGE}=$ reflux disease

The average value of BMI in the group of patients was $47.26 \mathrm{~kg} / \mathrm{m}^{2}(38-68)$ and in the control group of $24.21 \mathrm{~kg} / \mathrm{m}^{2}$ (21-28) (Table 1). Only one individual of patient group had BMI below $40 \mathrm{~kg} / \mathrm{m}^{2}$. Most of the control group was of normal individuals (70\%). 
The ones analyzed in the group of patients, 30 (85.7\%) did not use PPIs and five (14.3\%) yes. Sixteen of control group (53.3\%) used PPIs and 14 did not (Table 2).

Most patients were asymptomatic (91.4\%); in the three symptomatic the most prevalent symptom was heartburn. Most control subjects were symptomatic (80\%). The most prevalent symptom was epigastric pain.

Twenty-eight (80\%) patients had endoscopy with alterations and seven (20\%), normal. In the control group ten (33.3\%) had normal results and 20 (66.7\%) amended (Table 2). Twenty-six $(81.25 \%)$ of the 32 asymptomatic patients had endoscopy with alterations.

The endoscopic changes in the patient group were $57.1 \%$ $(n=20)$ resulting from ulceropeptic disease, 34.3\% $(n=12)$ associated with reflux disease, $11.4 \%(n=4)$ showed benign polyps and $8.6 \%(n=3)$ other findings - Zenker's diverticulum, esophageal and gastric intestinal metaplasia, subepithelial lesions (Figure 1, Table 2)

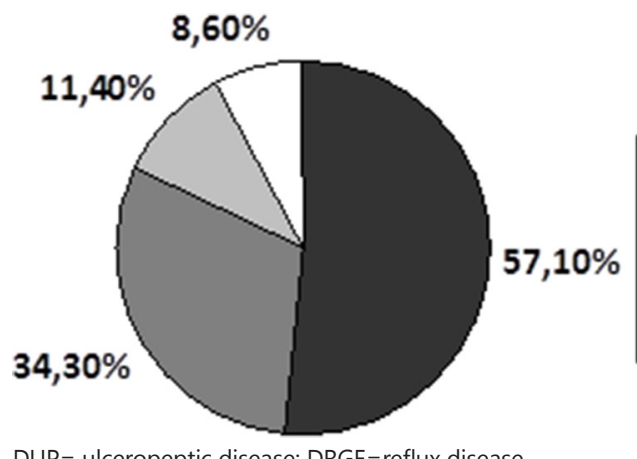

FIGURE 1 - Endoscopic findings in patients group

In the group of patients, the analysis of correlation between the increase in the value of BMI and the incidence of endoscopic findings was not statistically significant (Table 3). In the control group, the endoscopic findings were $50 \%(n=15)$ resulting from ulceropeptic disease, $23.3 \%(n=7)$ associated with reflux disease, two had benign polyps and two other findings, which were ectopic pancreas and ectopic gastric mucosa in proximal esophagus (Figure 2; Table 2).

TABLE 3 - Correlation analysis between the increase in the value of BMI and the incidence of endoscopic findings

\begin{tabular}{|c|c|c|}
\hline Variable & Statistic & IMC \\
\hline \multirow{2}{*}{ DUP } & Correlation coefficient $(r)$ & $+0,031$ \\
\hline & Calculated significance $(p)$ & 0,858 \\
\hline \multirow{2}{*}{ DRGE } & $n$ & 35 \\
\hline \multirow{2}{*}{ Polyp } & Correlation coefficient $(r)$ & $-0,271$ \\
\hline & Calculated significance $(p)$ & 0,115 \\
\hline \multirow{2}{*}{ Others } & $n$ & 35 \\
\hline & Correlation coefficient $(r)$ & $+0,013$ \\
\hline & Calculated significance $(p)$ & 0,939 \\
\hline & Calculated significance $(p)$ & 35 \\
\hline & $n$ & 0,232 \\
\hline
\end{tabular}

$\mathrm{DUP}=$ ulceropeptic disease $\mathrm{DRGE}=$ reflux disease

The analysis of the number of endoscopic findings in patients and in the control group did not show statistically significant differences (Table 4).

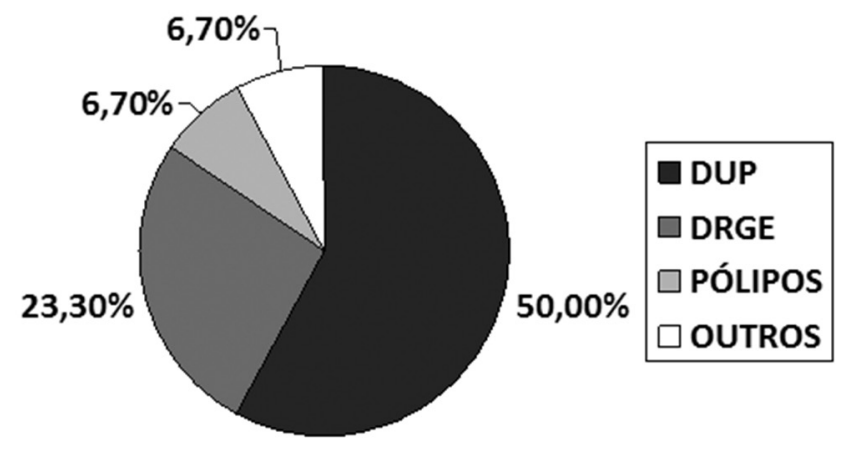

DUP = ulceropeptic disease; $D R G E=$ reflux disease

FIGURE 2 - Endoscopic findings in control group

TABLE 4 - Analysis of endoscopic findings of the patients group compared to the control group

\begin{tabular}{|c|c|c|c|c|c|c|}
\hline \multirow{3}{*}{ Variable } & \multirow{3}{*}{ Category } & \multicolumn{4}{|c|}{ Group } & \multirow{3}{*}{$\mathbf{p}$} \\
\hline & & \multicolumn{2}{|c|}{ Patient } & \multicolumn{2}{|c|}{ Control } & \\
\hline & & Freq. & Perc. & Freq. & Perc. & \\
\hline \multirow{2}{*}{ DUP } & Yes & 20 & $57,10 \%$ & 15 & $50,00 \%$ & \multirow{2}{*}{0,565} \\
\hline & No & 15 & $42,90 \%$ & 15 & $50,00 \%$ & \\
\hline \multirow{2}{*}{ DRGE } & Yes & 12 & $34,30 \%$ & 7 & $23,30 \%$ & \multirow{2}{*}{0,333} \\
\hline & No & 23 & $65,70 \%$ & 23 & $76,70 \%$ & \\
\hline \multirow{2}{*}{ Polyp } & Yes & 4 & $11,40 \%$ & 2 & $6,70 \%$ & \multirow{2}{*}{0,508} \\
\hline & No & 31 & $88,60 \%$ & 28 & $93,30 \%$ & \\
\hline \multirow{2}{*}{ Others } & Yes & 3 & $8,60 \%$ & 2 & $6,70 \%$ & \multirow{2}{*}{0,774} \\
\hline & No & 32 & $91,40 \%$ & 28 & $93,30 \%$ & \\
\hline
\end{tabular}

DUP $=$ ulceropeptic disease; $D R G E=$ reflux disease

The prevalence of Helicobacter pylori infection was $60 \%$ $(n=21)$ individuals in the group of patients and in $40 \%(n=12)$ in the control group (Table 2).

\section{DISCUSSION}

In this study, $97.1 \%(n=34)$ of patients preoperatively showed IMC $\geq 40$, being included, therefore, in a group of severely obese, whose surgical treatment may bring good results.

There are studies showing that most individuals in the preoperative bariatric surgery does not have symptoms of reflux ${ }^{5}$. In this study, the majority of individuals in the group of patients were asymptomatic (91.4\%) and 30 (85.7\%) did not use PPIs. The most common symptoms were heartburn and epigastric pain between symptomatic individuals from groups of patients and control.

There is published data that showed endoscopic findings in patients in the preoperative bariatric surgery ranging between $9.5 \%$ and $90 \%$, most of them between $18 \%$ and $54 \%$.

In this study, $81.25 \%(n=26)$ of asymptomatic individuals in the group of patients had alterations in endoscopic examination, confirming some studies showing endoscopic findings in $80 \%$ of asymptomatic patients ${ }^{7,8}$.

Endoscopic changes in the patient group were $57.1 \%$ $(n=20)$ resulting from ulceropeptic disease and $34.3 \%(n=12)$ associated with reflux disease, corroborating data in the literature which show that the most frequent endoscopic findings are gastritis, hiatal hernia, esophagitis and gastroduodenal ulcers $s^{4,7,8}$. Individuals analyzed in this study had no endoscopic finding that could contraindicate bariatric surgery.

In the group of patients, the analysis of correlation between the increase in the value of BMI and the incidence of endoscopic findings was not statistically significant, suggesting that there is no relationship between the degree of obesity and the occurrence of endoscopic changes.

The analysis of the number of endoscopic findings in patients in the control group did not show statistically significant differences, which may suggest that obese individuals have no 
higher probability of having endoscopic changes.

The prevalence of Helicobacter pylori in this study was $60 \%$ $(n=21)$ in the group of patients. In the literature, its prevalence in individuals with bariatric surgery indication varies from $8,7 \%^{5}$ a $30-40 \%^{4,11}$. The finding of this study may have been due to the use of two methods for the bacteria search (urease test and histology), which increased the accuracy. One should also take into account that there are papers that used only one diagnostic method and others investigated Helicobacter pylori only in part of their series. However, it is recommended to look for and treat it in the pre-operative period, since it is associated with higher incidence of gastric cancer ${ }^{12}$ and mouth ulcers in the anastomoses ${ }^{4}$.

\section{CONCLUSION}

It is recommended that endoscopy should be performed in all patients in the preoperative of bariatric surgery, although the degree of obesity is unrelated to larger endoscopic changes. The obese do not have more endoscopic changes than the non-obese.

\section{REFERENCES}

1. Associação Brasileira para o Estudo da Obesidade e da Síndrome Metabólica. Diretrizes brasileiras de obesidade 2009/2010. $3^{\text {a }}$ ed. Itapevi (SP): AC Farmacêutica; 2009.

2. NHLBI [homepage on the internet]. Clinical Guidelines on the Identification, Evaluation, and Treatment of Overweight and Obesity in Adults. Acesso em: 22 Jan 2014. Disponível em: http://www.nhlbi. nih.gov/guidelines/obesity/ob_home.htm

3. SBCBM [homepage on the internet]. Obesidade: pesquisas. Acesso em: 22 Jan 2014. Disponível em: < http://www.sbcb.org.br/obesidade. php?menu $=4>$
4. Anderson MA, Gan SI, Fanelli RD, Baron TH, Banerjee S, Cash BD, et al. ASGE guideline: Role of endoscopy in the bariatric surgery patient. Gastrointest Endosc 2008; 68: 1-10

5. Küper MA, Kratt T, Kramer KM, Zdichavsky M, Schneider JH, Glatzle J, et al. Effort, safety, and findings of routine preoperative endoscopic evaluation of morbidly obese patients undergoing bariatric surgery. Surg Endosc. 2010; Aug; 24(8): 1996-2001

6. Campos JM, Silva LB, Pereira EF, Neto MPG. Endoscopia na Obesidade. In: Averbach $\mathrm{M}$ et al, editores. Endoscopia digestiva - diagnóstico e tratamento, SOBED. Rio de Janeiro: Revinter; 2013. p. 393-403

7. D'HondtM,SteverlynckM,Pottel H, ElewautA, George C, Vansteenkiste $\mathrm{F}$, et al. Value of preoperative esophagogastroduodenoscopy in morbidly obese patients undergoing laparoscopic Roux-en-Y gastric bypass. Acta Chir Belg. 2013; Jul-Aug; 113 (4): 249-53

8. Sharaf RN, Weinshel EH, Bini EJ, Rosenberg J, Sherman A, Ren CJ. Endoscopy plays an important preoperative role in bariatric surgery. Obes Surg. 2004; Nov-Dec; 14(10): 1367-72

9. Gordejuela AG, Gebelli JP. Endoscopia Preoperatoria - Indicación Selectiva.In:Campos Jetal, editores. Endoscopia bariátrica terapêutica: casos clínicos e vídeos. Rio de Janeiro: Revinter; 2014. p. 45-46

10. Sauerland S, Angrisani L, Belachew M, Chevallierv JM, Favretti F, Finer N, et al. European Association for Endoscopic Surgery. Obesity surgery: evidence-based guidelines of the European Association for Endoscopic Surgery (EAES). Surg Endosc. 2005; 19:200-21

11. Almeida AM, Cotrim HP, Santos AS, Bitencourt AG, Barbosa DB, Lobo AP, et al. Preoperative upper gastrointestinal endoscopy in obese patients undergoing bariatric surgery: is it necessary? Surg Obes Relat Dis. 2008; Mar-Apr; 4(2):144-9

12. Malfertheiner P, Megraud F, O'Morain CA, Atherton J, Axon ATR, Bazzoli F, et al. Management of Helicobacter pylori infection - the Maastricht IV/ Florence Consensus. Gut 2012; 61: 646-664 